\title{
Investment Experience, Bilateral Investment Treaty and China's ODI: A New Angle to Explain Risk Preference
}

\author{
Peiyuan $\mathrm{Xu}^{1} \&$ Yongzhong Wang ${ }^{2}$ \\ ${ }^{1}$ School of Economics and Management, Tsinghua University, Beijing, China \\ ${ }^{2}$ Institute of World Economics and Politics, Chinese Academy of Social Sciences, Beijing, China \\ Correspondence: Peiyuan Xu, School of Economics and Management, Tsinghua University, Beijing, Haidian \\ District, China. E-mail: xupeiyuan123@gmail.com
}

Received: October 20, 2019

doi:10.5539/ijbm.v15n1p109

\begin{abstract}
This paper investigates the role of investment experience in Chinese outward direct investment based on deal-level data from FDI Intelligence and Dealogic data. We use gravity model to test the Chinese firm's risk attitude and how this attitude is adjusted by firm's previous investment experience and Bilateral Investment Treaty (BIT). The results show that, first, investment experience has a stimulating effect on s (next) investment scale. This stimulating effect is positively correlated with the concreteness of the investment experience; Second, China's ODI still has an appetite. Firms tend to investing in countries of high corruption risk, government efficiency risk, political stability risk, regulation quality risk and rule of law risk, but not voice and accountability risk; Third, previous investment experience has a moderating effect on risk preference. That is to say, firms with richer experience tend to be more risk averse; Finally, the existence of investing partner does have a positive moderating effect on firms' risk preference making firms more risk averse, while the BIT has a stronger but negative moderating effect on risk preference, making firms more aggressive, especially for resource industry. It is inferred that BIT provides a solid safety net for Chinese resource companies since they're mostly state-owned and have keen relationship with Chinese government.
\end{abstract}

Keywords: investment experience, risk preference, moderating effect, outward direct investment

\section{Introduction}

\subsection{China's Outward Direct Investment}

Foreign direct investment (FDI) constitutes an important part in international business. In 2018, the global foreign direct investment has declined $13 \%$ to $\$ 1.3$ trillion and it is the second time that FDI from developing countries surpasses that from developed countries (the first time occurred in 2014). This is mainly due to large repatriations of accumulated foreign earnings by United States multinational enterprises (MNEs) in the first two quarters of 2018, following tax reforms introduced at the end of 2017 (World Investment Report, 2019). On the other side, FDI from developing countries have been steadily increasing, especially China.

After the "Go global" policy, China's outward direct investment (hereafter "ODI") has maintained rapid growth for a long time. Since 2015, China's ODI has been among the top three in the world for three consecutive years, with 2015 and 2016 ranking the second in the world. Since the Chinese government first announced the official aggregate data of year 2002 in 2003, China's investment has increased by 57.6 and 59.5 times in terms of flow and stock respectively, at an average annual growth rate of $28.98 \% / 29.23 \%$. China's ODI stock in 2017 ranked $2^{\text {nd }}$ compared to $6^{\text {th }}$ in previous year according to 2018 Statistical Bulletin of China's Outward Foreign Direct Investment (hereafter "the Bulletin"). With the deepening of "Go global" policy and the implementation of the "One Belt \& One Road" initiative, China's ODI is bound to continue increasing. Normally, scale is the enemy of profitability. Given the volume and high speed of growth, China's oversea asset security becomes a severe task.

\subsection{Challenge for China's ODI}

As a latecomer of foreign investment, China has attracted whole world's attention for its aggressiveness in foreign investment. As China realizes more investment, troubles and failures emerges. For example, Shougang encountered consecutive troubles with labor union after the acquisition of Peruvian iron ore in 1992 (Guo, 2015); China Minmetal's failure in acquiring Chile's national copper company-Codelco mine equity in 2008 due to 
internal opposition in Codelco'; China Railway Construction Corporation's high-speed rail project of was indefinitely suspended by the Mexican government for "violating environmental regulations and long-term overdue fines" in 2015 , etc.

Like all investment, China's ODI can not be all successful. As the biggest developing country and socialist country, it is interesting to know companies from this country is different from developed countries' companies. As a matter of fact, according to the China's Outwards Direct Investment Bulletin (2018), the first 20 host countries attract $91.7 \%$ of China's ODI in terms of stock and developing economies receives $80 \%$, most of which are considered as risky countries with low level institution quality. However, apart from risk level, there're many other factors have effect on ODI's location. Therefore, we can only say Chinese companies seem to have an appetite for high risk countries.

This is not and should not be the final answer. In 2018, China's ODI is positioned $3^{\text {rd }}$ in terms of stock. It is important to know Chinese companies' real risk appetite and reason for having that appetite. The answers not only help shareholders of these companies to know if their money is used properly, but also help the rest of the World to know if Chinese companies are indeed behaving differently from companies of western countries.

\subsection{Literature Review}

Multinationals realizes FDI with various motivations. On the one hand, firms to expand their boundary with motivations including resource-seeking, market-seeking, technology-seeking, among other. On the other hand, local firms can benefit from FDI activities. Multinationals can bring new technology, better management practice, know-how, stronger internal finance support to local firms (Arnold \& Javorcik, 2009). Given this benefit, local government always welcome FDI and provide different convenience to these multinationals. For example, low tax rate, high government efficiency, strict law enforcement, etc.

Intuitively, FDI is attracted to countries with high quality of infrastructure, impartial legal system, efficient government. Empirical studies based on developed countries have provided abundant evidence on the positive relationship between countries institutional quality and FDI (Asiedu, 2006; Gani, 2007; Globerman \& Shapiro, 2002; Wei, 2000; Lu, 1999). High-quality infrastructure ensures stable and secured production; efficient government helps the FDI source companies shorten the administrative work time and thus enhance profitability; impartial legal and strict law enforcement system keep the private property under protection. Therefore, it is logic and expected to see FDI is attracted to low risk countries.

However, research on China's ODI exhibits different results. Buckley et al. (2007, 2009) found that China's approved FDI outflow from 1984-2001 was negatively correlated with the institutional quality of the host country. Ramasamy, Yeung, and Laforet (2012) identified that Chinese state-owned enterprises behaves differently from privately owned companies based on 200 listed companies' data. The state-controlled firms are attracted to countries with large natural resources and risky political environments while private firms are more market seekers. They attributed this phenomenon to the good relationship between China's firms and governments, which gives them the Special Ownership Advantages (SOA) to tolerate a higher risk level. An example of SOA is that SOEs have access to bank loan at a significant lower interest rate than private enterprises. Kolstad and Wiig (2012) did not find that the institutional risk of the host country had a significant impact on China's ODI, but the coefficient of interaction term between natural resources and institutional risk was negative, suggesting that China's resource-seeking ODI took advantage of the imperfect institution of developing countries to plunder resources; Wang and Zhao (2016) found that China's ODI from 2004-2013 was attracted to high risk countries.

The conclusion that China's ODI prefers high-risk countries is opposed by some other scholars, who found that China's ODI is not fundamentally different from that of developed countries and prefer low-risk countries to high-risk countries, or indifferent to risks.

One important reason proposed by these scholars was that when studying the FDI location determinants, previous studies only considered characteristics of host countries, since only aggregate level ODI data is published by Chinese government, firm-level factors are omitted and the results should be biased. Therefore, scholars began to use firm-level or deal-level data to analyze China's ODI and found some different conclusions. Zong, $\mathrm{Lu}$, and $\mathrm{Wu}$ (2012) studied 92 firms' 287 subsidiaries in 60 countries from 2003 to 2009 and found that after controlling firm size, age, investment experience and equity nature, host countries' institution quality(risk) was positively correlated with the investment decision (invest or not); Wang, Du, and Wang (2014) using conditional logit model analyzed 842 deal-level Chinese merge and acquisition data and found that after controlling firm-level total assets, ROA and P/E ratio, Chinese firms did not care much about the political regime or political stability of the host country, but were concerned about government efficiency, regulatory quality and 
corruption control, and tended to avoid countries with strict laws.

Another reason is that since investment flow is not a random sample (very risky countries may not receive any investment and hence will not be observed), the so-called risk-preference phenomenon may be a result of sample self-selection and the estimated coefficients under OLS will be biased. Various articles analyzed investment choice and scale separately using Heckman two stage model. Jiang and Jiang (2012a) discovered that host countries' political stability and regulation quality only affect China's investment decision but not scale, while ODI scale is negatively affected by the level of rule of law but positively affected by level of corruption control. Wang and Xiang (2015) found that the investment decision and scale behave differently: investment scale prefers to advantageous institutional environment. However, not all types of ODI prefer countries with good institutional environment. Specifically, for technology-seeking ODI, host countries' institutional quality is not a priority factor and this type of ODI prefers to countries with poor institutional environment. While investment decision prefers to disadvantageous institutional environment. Liu, Liu, and Li (2016) found that risk preference in general does not exist. Jiang and Jiang (2012b) found no significant correlation between host countries' risk and China ODI.

To sum up, it is still hard to give a final answer to the question whether China's ODI prefers high risk countries or not. A dynamic perspective should be applied to see if Chinese multinationals have made any progress. Unfortunately, existing literature fails to include this dynamic when analyzing Chinese companies risk attitudes or fair to quantify it. For example, Zong, Lu and Wu (2012), Chen, Tian and Han (2018) considered the previous investment experience's effect but they only recorded that if the firm had any previous investment in this country. That means a one-time investment experience is treated equally with $\mathrm{N}$-time experience. However, this precondition is questionable and needs to be further tested. Being a socialist country, China attracts more attention. It is interesting to know whether International Business theory developed from western countries can be applied to socialist countries and to see if Chinese firms have experienced any changes/evolution during years of high-speed growth.

\subsection{Analysis and Hypotheses}

It is true that, compared with enterprises in developed countries, Chinese enterprises are still inexperienced in understanding other countries' socioeconomic and cultural environment, resulting in insufficient risk control measures. However, we have to keep in mind that Chinese companies have been in rapid growth in recent decades. During this process, many Chinese companies started their outwards direct investment as an amateur but have accumulated abundant investment experience (successful and unsuccessful). For example, Latin American countries tend to have a stronger labor union and thus have stronger bargaining power, which is quite opposite situation in China where labor union has little bargaining power compared to the management. Therefore, dealing with labor union in other countries is quite difficult for Chinese firms. At the beginning, Chinese companies didn't do well but are improving (Guo, 2015). Once Chinese companies complete the transformation from naïve firms to mature firms, their investment behavior might be different. Given that Chinese firms learn from past unsuccessful experience, we can infer that Chinese's previous investment will have a significant effect on its attitudes towards the risk and we name this effect the moderating effect of (previous) investment experience. Hence the first hypothesis to be tested is:

H1: Previous investment experience has a positive moderating effect on risk (More experience means more risk averse)

Another potential important issue is that, at the early stage of ODI, resource-seeking the main goal (Ge \& Yan, 2012). For example, in Latin America, Chinese ODI mainly concentrated in metal and nonmetal mineral resource (Wang \& Xu, 2018). However, countries that would allow Chinese companies to invest were those countries with poor institutions, mainly distributed in Africa and Latin America. Although United States, Australia, Canada and other western countries also have abundant natural resources and of low risk, they do not allow Chinese ODI to invest. Therefore, Chinese firms in above mentioned industries had to invest in countries with higher risk in order to satisfy domestic demand. Knowing this dilemma, Chinese government has tried to alleviate the country risk by signing Bilateral Investment Treaty (BIT) to provide special protection for Chinese firms in certain countries. With these BITs effective, Chinese companies are able to invest in risky countries. if this is the case, Chinese firms will invest more in high risk but with a BIT effective country. Thus, the risk scores evaluated by international organizations are not suitable for describing the real risk level faced by Chinese companies. In fact, the scores overestimate the risk level in host countries. Hence the second hypothesis to be tested is:

H2: Bilateral investment treaty has a negative moderating effect on risk (Existence of effective BIT means less 
risk averse)

Along with Chinese technology development, China's ODI began to diversify. Industries like electronic generation, high-speed railway/road construction and utilities became another important source of ODI thanks to their increased international competitiveness. If Chinese resource-seeking ODI does not have much choice on location, market-seeking may have more choices. Since many market-seeking companies are private companies, they don't have the social responsibility as state-owned companies and hence may care risk level more. This is also confirmed by Ramasamy, Yeung, and Laforet (2012) and Amighini, Rabellotti, and Sanfilippo (2013). Hence the third hypothesis to be tested is:

\section{H3: state-owned enterprises are less risk averse than private-owned companies}

Therefore, this paper tries to answer the following two questions: whether Chinese companies have a so-called appetite for high risk countries and possible explanations for Chinese firms' risk-seeking impression.

\section{Method}

\subsection{Model}

We employ Least Square Dummy Variable (LSDV) model to capture both firm-level heterogeneous characteristics (investment experience) and macro-level country characteristics. Since we have to preserve firm-level factors, deal-level dataset is used. However, the dataset is not panel data, since exists situations where one firm invested in several countries in one year. Variables are chosen according to Buckley et al. (2007), Zong, $\mathrm{Lu}$ and $\mathrm{Wu}$ (2012), Jiang and Jiang (2012a, 2012b).

The model is as follows:

Where $\exp _{i}$ can be $\exp C_{i}, \exp R_{i^{\prime}}, \exp W_{i}$

$$
\begin{aligned}
\ln _{\text {AdjInv }_{i}=\beta_{o}} & +\beta_{1} \text { lncgdp }_{i}+\beta_{2} \text { ln hgdp }_{i}+\beta_{3} \text { rwage }_{i} \\
& +\beta_{4} \text { lpatent }_{i}+\beta_{5} \text { ldist }_{i}+\beta_{6} \text { bit }_{i}+\beta_{7} \text { resource }_{i} \\
& +\beta_{8} \text { green }_{i}+\beta_{9} \text { partn }_{i}+\beta_{10} \text { exp }_{\text {im }}+\beta_{11} \text { wgi }_{i} \\
& +\beta_{12} \text { exp }_{\text {im }} * \text { wgi }_{\text {in }}+\beta_{13} \text { bit }_{i} * \text { wgi }_{\text {in }}+\beta_{14} \text { year }_{i} \\
& +\beta_{15} \text { industry }_{i}+\varepsilon_{i}
\end{aligned}
$$

$$
\begin{gathered}
w_{\text {gin }} \in\left\{\text { cce }_{i}, \text { gee }_{i}, \text { pse }_{i}, \text { rqe }_{i}, \text { rle }_{i}, \text { vae }_{i}\right\} \\
\frac{\partial \ln \text { AdjInv }_{i}}{\partial w g i_{i}}=\beta_{11}+\beta_{12} \exp _{i m}+\beta_{13} \text { bit }_{i}
\end{gathered}
$$

The direct effect of risk is represented by $\beta_{11}$; The moderating effect of investment experience (H1) and moderating effect of BIT (H2) are captured by $\beta_{12}$ and $\beta_{13}$ correspondingly. If $\beta_{12 / 13}$ is positive(negative), this means that experience/BIT positively(negatively) adjusting firm's risk attitude, making firm more risk averse/preference. Thus, $\mathrm{H} 1$ and $\mathrm{H} 2$ are verified. We test $\mathrm{H} 3$ by compare coefficients in resource industries where SOEs have monopoly power and coefficients in other industries where private firms are more competitive.

\subsection{Variables}

$\ln A d j I n v_{i}$ is the logarithm value of deal-level investment log value in 2010 constant US dollars of observation $\mathrm{i} ;{ }^{2}$

$\ln c g d p_{i}$ is the logarithm value of China's GDP in 2010 constant US dollars before the investment i realized;

$\ln h g d p_{i}$ is the logarithm value of host country's GDP 2010 constant US dollars before the investment i realized; rwage $_{i}$ is the relative wage of the host country, calculated by dividing host coutry's GDP per capita (of the year before investment $\mathrm{i}$ in 2010 US dollar value) with China's GDP per capita (of the year before investment $\mathrm{i}$ in 2010 US dollar value);

lpatent $_{i}$ is the logarithm of the number of patent applications received by WIPO's international office in the host country and represents the host country's innovation capacity;

ldist $_{i}$ is the product of geographic distance of China-host country and international oil price (in 2010 US dollar value) in the year when investment was realized;

bit $_{i}$ is dummy variable and equals 1 if that year there is a valid bilateral investment treaty effective between China and the host country;

green $_{i}$ is the dummy variable of entry mode (greenfield investment takes value 1), which is used to control the 
influence of entry mode on investment scale;

$w g i_{i}$ is the world governance index, which contains six sub-indicators to measure the quality of governance. We use these indicators to capture country risk (Buckley et al., 2007; Jiang \& Jiang, 2012a). Six categories cover corruption control(cce), political stability(pse), regulation quality(rqe), rule of law(rle) and voice and accountability(vae). The higher the score, the better the quality of governance;

$\exp _{i}$ represents the firm's previous investment experience in this country/region/world when it conducts investment $\mathrm{i}$, denoted by $\exp C_{i}$, $\exp R_{i}$ and $\exp W_{i}$ respectively. We make this distinction between experience accumulated at different geographic level based on the following idea: The investment experience is composed by two terms: general experience and country specific experience. General experience is knowledge that can be used in every country, such as preparing an internationally accepted technical offer and economic offer; specific experience is knowledge only accumulated in certain country and can be only (re)used in the same country (sometimes this knowledge may also apply to similar countries). In fact, $\exp C_{i}, \exp R_{i}$ and $\exp W_{i}$ are all combination of general knowledge and specific countryknowledge. However, we assume that $\exp _{i}$ contains country specific knowledge mostly, while $\exp W_{i}$ contains general investment knowledge most and $\exp R_{i}$ a balanced measure of specific and general knowledge. These three variables are hand-collected.

year $_{i}$ and industry $_{i}$ are dummy variables of the year and the investment target industry, respectively. To make the data comparable from year to year, the author used the U.S. GDP deflator to convert all the amount of data into the $\mathbf{2 0 1 0}$ constant dollar value (See

Table 1).

Table 1. Variables and expected sign

\begin{tabular}{lllll}
\hline Variables & Source & Exp.Sign & Variables & Source \\
\hline lnAdjInv & fDi Intelligence, Dealogic & & lpatent & WIPO \\
expC & fDi Intelligence, Dealogic & + & ldist & Mayer and Zignago (2011), EIA \\
expR & fDi Intelligence, Dealogic & + & rwage & World Bank \\
expW & fDi Intelligence, Dealogic & + & cce & World Governance Indices \\
lncgdp & World Bank & + & gee & World Governance Indices \\
lnhgdp & World Bank & + & pse & World Governance Indices \\
bit & UNCTAD, MOFCOM & + & rqe & World Governance Indices \\
partn & fDi Intelligence, Dealogic & + & rle & World Governance Indices \\
green & fDi Intelligence, Dealogic & - & & \\
\hline
\end{tabular}

\subsection{Sample}

\subsubsection{Sample Source and Summary Statistics}

Our investment dataset consists of green field investment data and merge \& acquisition data. They come from FDI Intelligence and Dialogic, respectively. Both two datasets provide information of investing body's name, industry, investment value, target country. Country risk data were derived from the world bank world governance index (WGI); Patent data is from World Intellectual Property Organization; Oil price is from the U.S. energy information administration (EIA); the geographic distance data is from Mayer and Zignago (2011); Other control variables were from the World Bank database.

The time span is 1998 - 2016, covering 114 countries/regions, with a total of 6345 observations. Among 6345 observations, 4912 are the first-time investments in the target country; 821 investments are second time investment in the target country; 296 investments are the third time; 316 are the fourth time. There're 913 investing bodies. ${ }^{3}$ 
Table 1. Summary Statistics

\begin{tabular}{|c|c|c|c|c|c|c|}
\hline & Variables & Obs & Mean & Std & Min & Max \\
\hline \multirow[t]{5}{*}{ Dependent Variable } & lnAdjInv & 6,345 & 16.68 & 2.30 & 6.82 & 24.42 \\
\hline & $\operatorname{expC}$ & 6,345 & 0.45 & 1.15 & 0.00 & 15.00 \\
\hline & $\operatorname{expR}$ & 6,345 & 1.92 & 6.17 & 0.00 & 76.00 \\
\hline & $\operatorname{expW}$ & 6,345 & 6.21 & 18.46 & 0.00 & 174.00 \\
\hline & cce & 6,345 & 0.99 & 1.05 & -1.52 & 2.47 \\
\hline \multirow[t]{9}{*}{ Independent Variables } & gee & 6,345 & 1.09 & 0.88 & -1.65 & 2.44 \\
\hline & pse & 6,345 & 0.38 & 0.81 & -2.81 & 1.61 \\
\hline & rqe & 6,345 & 1.07 & 0.92 & -2.16 & 2.26 \\
\hline & rle & 6,345 & 1.00 & 0.95 & -1.92 & 2.10 \\
\hline & vae & 6,345 & 0.61 & 0.82 & -2.25 & 1.74 \\
\hline & $\operatorname{lncgdp}$ & 6,345 & 29.51 & 0.34 & 28.28 & 29.88 \\
\hline & lnhgdp & 6345 & 27.51 & 1.79 & 20.35 & 30.46 \\
\hline & lpatent & 6,345 & 9.52 & 2.72 & 0.00 & 13.31 \\
\hline & ldist & 6,345 & 12.83 & 0.85 & 9.92 & 14.47 \\
\hline \multirow{4}{*}{ Control Variables } & rwage & 6,345 & 2.62 & 2.20 & -0.94 & 19.84 \\
\hline & green & 6,345 & 0.52 & 0.50 & 0.00 & 1.00 \\
\hline & partn & 6,345 & 0.05 & 0.21 & 0.00 & 1.00 \\
\hline & bit & 6,345 & 0.68 & 0.47 & 0.00 & 1.00 \\
\hline
\end{tabular}

Table 3. Correlation

\begin{tabular}{|c|c|c|c|c|c|c|c|c|c|c|c|c|c|c|c|}
\hline & expC & expR & $\operatorname{expW}$ & lncgdp & lnhgdp & lpatent & ldist & partn & rwage & cce & gee & pse & rqe & rle & vae \\
\hline $\operatorname{expC}$ & 1 & & & & & & & & & & & & & & \\
\hline $\operatorname{expR}$ & 0.473 & 1 & & & & & & & & & & & & & \\
\hline expW & 0.403 & 0.826 & 1 & & & & & & & & & & & & \\
\hline lncgdp & 0.088 & 0.075 & 0.098 & 1 & & & & & & & & & & & \\
\hline lnhgdp & 0.051 & -0.051 & -0.037 & 0.179 & 1 & & & & & & & & & & \\
\hline lpatent & 0.067 & -0.082 & -0.084 & 0.116 & 0.829 & 1 & & & & & & & & & \\
\hline ldist & 0.008 & -0.002 & 0.065 & 0.055 & 0.334 & 0.019 & 1 & & & & & & & & \\
\hline partn & 0.077 & -0.013 & -0.026 & 0.083 & 0.080 & 0.094 & -0.019 & 1 & & & & & & & \\
\hline rwage & -0.032 & -0.064 & -0.108 & -0.451 & 0.182 & 0.260 & -0.123 & 0.017 & 1 & & & & & & \\
\hline cce & 0.035 & -0.055 & -0.093 & 0.018 & 0.338 & 0.432 & -0.006 & 0.074 & 0.693 & 1 & & & & & \\
\hline gee & 0.032 & -0.055 & -0.100 & 0.070 & 0.373 & 0.504 & -0.101 & 0.082 & 0.694 & 0.963 & 1 & & & & \\
\hline pse & 0.025 & -0.040 & -0.080 & 0.011 & 0.135 & 0.271 & -0.085 & 0.062 & 0.640 & 0.841 & 0.827 & 1 & & & \\
\hline rqe & 0.047 & -0.056 & -0.100 & 0.058 & 0.299 & 0.450 & -0.118 & 0.084 & 0.678 & 0.944 & 0.960 & 0.826 & 1 & & \\
\hline rle & 0.045 & -0.053 & -0.092 & 0.110 & 0.442 & 0.530 & -0.012 & 0.089 & 0.632 & 0.966 & 0.969 & 0.820 & 0.949 & 1 & \\
\hline vae & 0.047 & -0.060 & -0.068 & 0.089 & 0.579 & 0.512 & 0.306 & 0.072 & 0.336 & 0.723 & 0.682 & 0.560 & 0.688 & 0.777 & 1 \\
\hline
\end{tabular}

\section{Results}

\subsection{Basic Knowledge of Chinese Investment Path}

We calculated each investment entity's previous investment experience in the hosting country to know whether this investment is the firm's first-time, second-time, third-time or fourth time investment. We find the following patterns. First, Chinese firms prefer to invest in Hong Kong as a first stop. This is reasonable since Hong Kong has advanced financial industry, low capital tax and acts as a financial center in Southeast Asia. Many Chinese companies may choose to set a holding company to manage their global assets. Among all the initial investments of Chinese enterprises (4912), 652 projects (13.27\%) were invested in Hong Kong; Second, Chinese companies prefer advanced economy to developing economies, no matter measured by value or frequency. When measured by value, it's easy to observe more developing economies, such as Indonesia, Peru, Brazil, Kazakhstan. However, Indian disappeared in Table 4 Panel B. Probably because India attracts many investments small in size. 
Table 2. Chinese Companies' top 5 favorite host country/region 1998-2016

\begin{tabular}{|c|c|c|c|c|c|}
\hline \multicolumn{6}{|c|}{ Panel A: China's ODI Top 5 Favorite Host Area by Investment Frequency } \\
\hline & $1^{\text {st }}$ Target Area & $2^{\text {nd }}$ Target Area & $3^{\text {rd }}$ Target Area & $4^{\text {th }}$ Target Area & $5^{\text {th }}$ Target Area \\
\hline First-time & Hong Kong & U.S. & Germany & Australia & United Kingdom \\
\hline Second-time & Hong Kong & U.S. & Australia & Germany & India \\
\hline Third-time & U.S. & Australia & Hong Kong & Germany & Canada \\
\hline Fourth-time and above & U.S. & Hong Kong & Australia & India & Germany \\
\hline \multicolumn{6}{|c|}{ Panel B: China's ODI Top 5 Favorite Host Area by Investment Value } \\
\hline & $1^{\text {st }}$ Target Area & $2^{\text {nd }}$ Target Area & $3^{\text {rd }}$ Target Area & $4^{\text {th }}$ Target Area & $5^{\text {th }}$ Target Area \\
\hline First-time & U.S. & Switzerland & United Kingdom & Hong Kong & Indonesia \\
\hline Second-time & U.S. & Australia & Hong Kong & Peru & Canada \\
\hline Third-time & Canada & Australia & U.S. & Brazil & Hong Kong \\
\hline Fourth-time and above & Hong Kong & U.S. & Brazil & Kazakhstan & Canada \\
\hline
\end{tabular}

Source: Authors' caluculation based on fDi Intelligence, Dealogic.

\subsection{Does Investment Experience Promote more Investment?}

Investment is not often realized for just one time. Our empirical findings suggest that previous investment experience has a significant promotion effect on next-time investment scale and this promotion effect is increasing along with the concreteness of the information. Specifically, when the firm has 1 more previous investment experience in the host country, the next time investment will be $\mathbf{0 . 1 7 6 \%}$ larger in scale. Regional and world investment experience have similar effect. As the firm has 1 more previous investment experience in the host area/world, the next time investment will be $0.016 \% / 0.007 \%$ larger (see coefficients of expC, $\operatorname{expR,\operatorname {exp}W}$

Table 3, Table 4,

Table 5 respectively).

Table 3. China's ODI determinants and country investment experience

\begin{tabular}{lllllll}
\hline & $(1)$ & $(2)$ & $(3)$ & $(4)$ & $(5)$ & $(6)$ \\
& lnAdjInv & lnAdjInv & lnAdjInv & lnAdjInv & lnAdjInv & lnAdjInv \\
\hline RISK VAR(wgi) & CCE & GEE & PSE & RQE & RLE & VAE \\
lncgdp & 0.128 & 0.339 & -0.136 & 0.129 & 0.137 & $-0.469^{*}$ \\
& $(0.286)$ & $(0.293)$ & $(0.286)$ & $(0.285)$ & $(0.287)$ & $(0.282)$ \\
\hline
\end{tabular}




\begin{tabular}{lllllll}
\hline lnhgdp & $-0.120^{* * *}$ & $-0.117^{* * *}$ & $-0.145^{* * *}$ & $-0.152^{* * *}$ & $-0.086^{* *}$ & -0.027 \\
& $(0.036)$ & $(0.036)$ & $(0.037)$ & $(0.037)$ & $(0.036)$ & $(0.036)$ \\
lpatent & 0.016 & 0.032 & -0.005 & 0.037 & 0.018 & -0.033 \\
& $(0.022)$ & $(0.023)$ & $(0.022)$ & $(0.023)$ & $(0.022)$ & $(0.022)$ \\
ldist & $0.293^{* * *}$ & $0.208^{* * *}$ & $0.245^{* * *}$ & $0.253^{* * *}$ & $0.264^{* * *}$ & $0.285^{* * *}$ \\
& $(0.051)$ & $(0.051)$ & $(0.052)$ & $(0.052)$ & $(0.050)$ & $(0.053)$ \\
rwage & $0.036^{*}$ & $0.043^{*}$ & $-0.039^{* *}$ & $0.036^{*}$ & 0.020 & $-0.110^{* * *}$ \\
& $(0.021)$ & $(0.023)$ & $(0.020)$ & $(0.021)$ & $(0.020)$ & $(0.015)$ \\
green & $-0.632^{* * *}$ & $-0.625^{* * *}$ & $-0.570^{* * *}$ & $-0.648^{* * *}$ & $-0.634^{* * *}$ & $-0.613 * * *$ \\
& $(0.063)$ & $(0.063)$ & $(0.063)$ & $(0.063)$ & $(0.063)$ & $(0.064)$ \\
bit & $-0.379^{* * *}$ & $-0.357^{* * *}$ & $-0.515^{* * *}$ & $-0.415^{* * *}$ & $-0.312^{* * *}$ & $-0.286^{* * *}$ \\
& $(0.101)$ & $(0.111)$ & $(0.076)$ & $(0.115)$ & $(0.101)$ & $(0.090)$ \\
expC & $0.165^{* * *}$ & $0.158^{* * *}$ & $0.202^{* * *}$ & $0.172^{* * *}$ & $0.166^{* * *}$ & $0.190^{* * *}$ \\
& $(0.037)$ & $(0.044)$ & $(0.028)$ & $(0.043)$ & $(0.040)$ & $(0.035)$ \\
wgi & $-0.474^{* * *}$ & $-0.608^{* * *}$ & $-0.400^{* * *}$ & $-0.565^{* * *}$ & $-0.481^{* * *}$ & -0.124 \\
& $(0.076)$ & $(0.088)$ & $(0.097)$ & $(0.083)$ & $(0.077)$ & $(0.111)$ \\
expC* wgi & $0.051^{* *}$ & $0.050^{*}$ & 0.045 & 0.042 & $0.048^{*}$ & 0.050 \\
& $(0.025)$ & $(0.029)$ & $(0.031)$ & $(0.027)$ & $(0.027)$ & $(0.036)$ \\
bit*wgi & -0.091 & -0.091 & -0.045 & -0.109 & $-0.165^{* *}$ & $-0.327 * * *$ \\
& $(0.070)$ & $(0.076)$ & $(0.093)$ & $(0.078)$ & $(0.070)$ & $(0.102)$ \\
Constant & 13.141 & 7.862 & $22.406^{* * *}$ & $14.495^{*}$ & 12.332 & $28.870^{* * *}$ \\
& $(8.472)$ & $(8.645)$ & $(8.453)$ & $(8.432)$ & $(8.502)$ & $(8.406)$ \\
Obs. & 6,345 & 6,345 & 6,345 & 6,345 & 6,345 & 6,345 \\
Adjusted R2 & 0.191 & 0.189 & 0.182 & 0.192 & 0.192 & 0.186 \\
Year & YES & YES & YES & YES & YES & YES \\
Industry & YES & YES & YES & YES & YES & YES \\
\hline
\end{tabular}

Notes. 1. Since 6 risk variables are highly correlated, in regressions (1) - (6) we use different risk indicator to test China's ODI risk attitudes. These 6 risk variables are cce, gee, pse, rqe, rle and vae respectively; 2 . The parentheses are robust standard errors; $3 . * * * p<0.01, * * p<0.05$, $* \mathrm{p}<0.1$.

Table 4. China's ODI determinants and regional investment experience

\begin{tabular}{|c|c|c|c|c|c|c|}
\hline & (1) & (2) & (3) & (4) & (5) & (6) \\
\hline & InAdjInv & InAdjInv & lnAdjInv & InAdjInv & lnAdjInv & InAdjInv \\
\hline RISK VAR(wgi) & $\mathrm{CCE}$ & GEE & PSE & RQE & RLE & VAE \\
\hline \multirow[t]{2}{*}{$\operatorname{lncgdp}$} & 0.150 & 0.374 & -0.114 & 0.158 & 0.163 & -0.434 \\
\hline & $(0.287)$ & $(0.294)$ & $(0.287)$ & $(0.287)$ & $(0.288)$ & $(0.284)$ \\
\hline \multirow[t]{2}{*}{ lnhgdp } & $-0.122 * * *$ & $-0.119^{* * *}$ & $-0.146 * * *$ & $-0.153^{* * *}$ & $-0.087 * *$ & -0.028 \\
\hline & $(0.036)$ & $(0.036)$ & $(0.037)$ & $(0.037)$ & $(0.036)$ & $(0.036)$ \\
\hline \multirow[t]{2}{*}{ lpatent } & 0.025 & $0.042 *$ & 0.005 & $0.046^{* *}$ & 0.027 & -0.022 \\
\hline & $(0.022)$ & $(0.023)$ & $(0.022)$ & $(0.023)$ & $(0.022)$ & $(0.022)$ \\
\hline \multirow[t]{2}{*}{ ldist } & $0.302 * * *$ & $0.218^{* * *}$ & $0.254 * * *$ & $0.263 * * *$ & $0.273 * * *$ & $0.297 * * *$ \\
\hline & $(0.052)$ & $(0.051)$ & $(0.052)$ & $(0.052)$ & $(0.051)$ & $(0.053)$ \\
\hline \multirow[t]{2}{*}{ rwage } & 0.027 & $0.038^{*}$ & $-0.047 * *$ & 0.029 & 0.013 & $-0.116^{* * *}$ \\
\hline & $(0.021)$ & $(0.023)$ & $(0.020)$ & $(0.021)$ & $(0.020)$ & $(0.015)$ \\
\hline \multirow[t]{2}{*}{ green } & $-0.706^{* * *}$ & $-0.700 * * *$ & $-0.647 * * *$ & $-0.723 * * *$ & $-0.708 * * *$ & $-0.685^{* * *}$ \\
\hline & $(0.064)$ & $(0.064)$ & $(0.064)$ & $(0.064)$ & $(0.064)$ & $(0.064)$ \\
\hline \multirow[t]{2}{*}{ bit } & $-0.420 * * *$ & $-0.381 * * *$ & $-0.562 * * *$ & $-0.442 * * *$ & $-0.349 * * *$ & $-0.347 * * *$ \\
\hline & $(0.101)$ & $(0.112)$ & $(0.076)$ & $(0.116)$ & $(0.102)$ & $(0.090)$ \\
\hline \multirow[t]{2}{*}{$\operatorname{expR}$} & $0.016^{* * *}$ & 0.010 & $0.023 * * *$ & 0.011 & $0.015^{* *}$ & $0.022 * * *$ \\
\hline & $(0.006)$ & $(0.007)$ & $(0.005)$ & $(0.007)$ & $(0.007)$ & $(0.005)$ \\
\hline \multirow[t]{2}{*}{ wgi } & $-0.457 * * *$ & $-0.606^{* * *}$ & $-0.390 * * *$ & $-0.557 * * *$ & $-0.469 * * *$ & -0.136 \\
\hline & $(0.076)$ & $(0.088)$ & $(0.097)$ & $(0.083)$ & $(0.076)$ & $(0.112)$ \\
\hline \multirow[t]{2}{*}{$\operatorname{expR*wgi}$} & $0.012 * * *$ & $0.017 * * *$ & $0.014 * *$ & $0.016 * * *$ & $0.013 * * *$ & $0.009 * *$ \\
\hline & $(0.004)$ & $(0.005)$ & $(0.006)$ & $(0.005)$ & $(0.005)$ & $(0.005)$ \\
\hline \multirow[t]{2}{*}{ bit*wgi } & -0.109 & -0.120 & -0.073 & $-0.136^{*}$ & $-0.186 * * *$ & $-0.320 * * *$ \\
\hline & $(0.071)$ & $(0.077)$ & $(0.094)$ & $(0.079)$ & $(0.070)$ & $(0.103)$ \\
\hline \multirow[t]{2}{*}{ Constant } & 12.381 & 6.697 & $21.621 * *$ & 13.523 & 11.445 & $27.701 * * *$ \\
\hline & $(8.508)$ & $(8.678)$ & $(8.485)$ & $(8.465)$ & $(8.538)$ & $(8.444)$ \\
\hline Obs. & 6,345 & 6,345 & 6,345 & 6,345 & 6,345 & 6,345 \\
\hline Adjusted R2 & 0.184 & 0.183 & 0.175 & 0.186 & 0.185 & 0.179 \\
\hline Year & YES & YES & YES & YES & YES & YES \\
\hline
\end{tabular}




\begin{tabular}{|c|c|c|c|c|c|c|}
\hline Industry & YES & YES & YES & YES & YES & YES \\
\hline
\end{tabular}

Note: 1. Since 6 risk variables are highly correlated, in regressions (1) - (6) we use different risk indicator to test China's ODI risk attitudes. These 6 risk variables are cce, gee, pse, rqe, rle and vae respectively; 2 . The parentheses are robust standard errors; $3 .{ }^{* * *} \mathrm{p}<0.01,{ }^{* *} \mathrm{p}<0.05$, $* \mathrm{p}<0.1$.

Table 5. China's ODI determinants and world investment experience

\begin{tabular}{|c|c|c|c|c|c|c|}
\hline & (1) & (2) & (3) & (4) & (5) & (6) \\
\hline & $\ln A d j I n v$ & $\ln A d j I n v$ & $\ln A d j I n v$ & $\ln A d j I n v$ & lnAdjInv & lnAdjInv \\
\hline RISK VAR(wgi) & $\mathrm{CCE}$ & GEE & PSE & RQE & RLE & VAE \\
\hline \multirow[t]{2}{*}{$\operatorname{lncgdp}$} & 0.169 & 0.395 & -0.095 & 0.175 & 0.182 & -0.400 \\
\hline & $(0.286)$ & $(0.293)$ & $(0.287)$ & $(0.286)$ & $(0.287)$ & $(0.283)$ \\
\hline \multirow[t]{2}{*}{ lnhgdp } & $-0.113 * * *$ & $-0.109 * * *$ & $-0.136 * * *$ & $-0.144 * * *$ & $-0.077 * *$ & -0.013 \\
\hline & $(0.036)$ & $(0.036)$ & $(0.037)$ & $(0.037)$ & $(0.036)$ & $(0.036)$ \\
\hline \multirow[t]{2}{*}{ lpatent } & 0.020 & 0.036 & -0.001 & $0.040 *$ & 0.021 & -0.028 \\
\hline & $(0.022)$ & $(0.023)$ & $(0.022)$ & $(0.023)$ & $(0.022)$ & $(0.022)$ \\
\hline \multirow[t]{2}{*}{ ldist } & $0.277 * * *$ & $0.194 * * *$ & $0.225 * * *$ & $0.238 * * *$ & $0.250 * * *$ & $0.271 * * *$ \\
\hline & $(0.052)$ & $(0.051)$ & $(0.052)$ & $(0.052)$ & $(0.051)$ & $(0.053)$ \\
\hline \multirow[t]{2}{*}{ rwage } & 0.031 & $0.041^{*}$ & $-0.043 * *$ & 0.033 & 0.016 & $-0.111 * * *$ \\
\hline & $(0.021)$ & $(0.023)$ & $(0.020)$ & $(0.021)$ & $(0.020)$ & $(0.015)$ \\
\hline \multirow[t]{2}{*}{ green } & $-0.735 * * *$ & $-0.730 * * *$ & $-0.675 * * *$ & $-0.753 * * *$ & $-0.738 * * *$ & $-0.714 * * *$ \\
\hline & $(0.064)$ & $(0.064)$ & $(0.064)$ & $(0.064)$ & $(0.064)$ & $(0.064)$ \\
\hline \multirow[t]{2}{*}{ bit } & $-0.416^{* * *}$ & $-0.383 * * *$ & $-0.551 * * *$ & $-0.438 * * *$ & $-0.345 * * *$ & $-0.330 * * *$ \\
\hline & $(0.101)$ & $(0.111)$ & $(0.076)$ & $(0.115)$ & $(0.101)$ & $(0.090)$ \\
\hline \multirow[t]{2}{*}{$\operatorname{expW}$} & $0.007 * * *$ & $0.005^{* *}$ & $0.011 * * *$ & $0.005 * *$ & $0.006 * * *$ & $0.009 * * *$ \\
\hline & $(0.002)$ & $(0.002)$ & $(0.002)$ & $(0.002)$ & $(0.002)$ & $(0.002)$ \\
\hline \multirow[t]{2}{*}{ wgi } & $-0.483 * * *$ & $-0.630 * * *$ & $-0.411 * * *$ & $-0.580 * * *$ & $-0.496^{* * *}$ & -0.175 \\
\hline & $(0.076)$ & $(0.088)$ & $(0.097)$ & $(0.083)$ & $(0.077)$ & $(0.112)$ \\
\hline \multirow[t]{2}{*}{$\operatorname{expW} W^{*} w g i$} & $0.007 * * *$ & $0.008 * * *$ & $0.008 * * *$ & $0.009 * * *$ & $0.008 * * *$ & $0.007 * * *$ \\
\hline & $(0.001)$ & $(0.002)$ & $(0.002)$ & $(0.002)$ & $(0.002)$ & $(0.001)$ \\
\hline \multirow[t]{2}{*}{ bit*wgi } & -0.107 & -0.115 & -0.075 & $-0.137^{*}$ & $-0.185^{* * *}$ & $-0.318 * * *$ \\
\hline & $(0.071)$ & $(0.076)$ & $(0.093)$ & $(0.078)$ & $(0.070)$ & $(0.103)$ \\
\hline \multirow[t]{2}{*}{ Constant } & 11.926 & 6.182 & $21.156^{* *}$ & 13.128 & 10.963 & $26.647 * * *$ \\
\hline & $(8.481)$ & (8.654) & $(8.463)$ & (8.439) & $(8.511)$ & $(8.417)$ \\
\hline Obs. & 6,345 & 6,345 & 6,345 & 6,345 & 6,345 & 6,345 \\
\hline Adjusted R2 & 0.190 & 0.187 & 0.179 & 0.190 & 0.190 & 0.184 \\
\hline Year & YES & YES & YES & YES & YES & YES \\
\hline
\end{tabular}




\begin{tabular}{lllllll}
\hline Industry & YES & YES & YES & YES & YES & YES \\
\hline
\end{tabular}

Note: 1 . Since 6 risk variables are highly correlated, in regressions (1) - (6) we use different risk indicator to test China's ODI risk attitudes. These 6 risk variables are cce, gee, pse, rqe, rle and vae respectively; 2 . The parentheses are robust standard errors; 3 . *** $\mathrm{p}<0.01, * * \mathrm{p}<0.05$, $* \mathrm{p}<0.1$.

\subsection{China's ODI Risk Attitudes}

As discussed in Equation (2), a country's ODI risk attitudes is jointly affected directly by the country risk and moderated by the firm's specific ability (investment experience) and country's ability (Bilateral Investment Treaty). The coefficient of risk's direct effect $\left(\beta_{11}\right)$ is significant at 0.01 significance level. As the host country's risk level decreases 1 in score (wgi variable in creases by 1), the investment will be $0.400 \% \sim 0.630 \%$ larger in scale. However, this risk appetite does not exist for Voice and Accountability Risk. The coefficients of risk's moderating (indirect) effect are mostly significant at 0.1 significance level. As the firm has 1 more previous investment experience in host country/area/world, the risk preference attitudes will be reduced by $0.048 \% / 0.014 \% / 0.008 \%$. However, the moderating effect of BIT is different, when BIT exists, Chinese companies tend to invest $0.138 \% / 0.157 \% / 0.156 \%$ more in this country/region/world as risk score increases by 1 .

Table 6. Risk Preference of China's ODI

\begin{tabular}{cccc}
\hline & Direct Effect & \multicolumn{2}{c}{ Moderating Effect } \\
\hline Avearge & wgi: $\left(\beta_{11}\right)$ & exp*wgi: $\left(\beta_{12}\right)$ & bit*wgi $:\left(\beta_{13}\right)$ \\
$\mathbf{- 0 . 4 4 7}$ & $\mathbf{0 . 0 2 3}$ & $\mathbf{- 0 . 1 5 1}$ \\
\hline
\end{tabular}

Note. Since $\beta_{11}, \beta_{12}$ and $\beta_{13}$ are estimated 18 times, only mean values are reported here. See

Table 3, Table 4 and

Table $\mathbf{5}$ for more detall.

\section{Discussion}

\subsection{Risk Attitudes across Industries}

After many years' development, it is surprising to see that China's ODI is still attracted to high risk countries. We run the regression by industries and find that the risk preference is mainly caused by Oil and Non-oil mineral resources industry, Manufacture, Financial Services and Other indutries, ${ }^{4}$ since in our data set, the total investment in resources industry (Agriculture, Forestry, Animal Husbandry, Fishery, Mineral and Metal) constitute a $31.27 \%$ of total investment (115.00 billion US dollars). 
In Oil and Non-Oil Mineral resources industry and Financial Services industry, the risk's direct effect is significant at 0.01 level and the Bilateral Investment Treaty moderating effect is significant at 0.1 level, while investment experience does not have significant moderating effect on risk attitudes. If a country's regulation quality risk ( $\mathrm{rqe}$ ) reduces by 1 (risk score range is $-2.5^{\sim}+2.5$ ), the investment scale will be $0.96 \%$ higher. And if this country has an effective BIT with China, the investment scale will be $0.395 \%$ higher (in total, $1.355 \%$ ). Other types of risks (cce, gee, pse, rle and vae) have lower coefficients but the result remains (see

Table 7). ${ }^{5}$

In manufacture industry, the risk's direct effect is significant at 0.01 level, while experience and BIT's moderating effect mostly are not significant. In Other services industry, although investment scale has a strong preference for government efficiency risk and regulation quality risk ( $\beta_{11}$ are -16.712 and -12.656 respectively), the moderating effect is even stronger $\left(\beta_{13}\right.$ are 19.660 and 16.224 respectively).

The rest of the industries basically shows no preference or aversion to risk.

Table 7. Risk attitudes across selected industries

\begin{tabular}{|c|c|c|c|c|c|c|}
\hline Risk Var. Used & $\begin{array}{l}\text { InAdjInv } \\
\text { CCE }\end{array}$ & $\begin{array}{l}\ln A d j I n v \\
\text { GEE }\end{array}$ & $\begin{array}{l}\text { InAdjInv } \\
\text { PSE }\end{array}$ & $\begin{array}{l}\text { InAdjInv } \\
\text { RQE }\end{array}$ & $\begin{array}{l}\text { InAdjInv } \\
\text { RLE }\end{array}$ & $\begin{array}{l}\text { InAdjInv } \\
\text { VAE }\end{array}$ \\
\hline \multicolumn{7}{|c|}{ Metal and Non-Metal Mineral Resources Industry } \\
\hline wgi & $\begin{array}{l}-0.670 * * * \\
(0.216)\end{array}$ & $\begin{array}{l}-0.883 * * * \\
(0.253)\end{array}$ & $\begin{array}{l}-0.226 \\
(0.262)\end{array}$ & $\begin{array}{l}-0.960 * * * \\
(0.259)\end{array}$ & $\begin{array}{l}-0.642 * * * \\
(0.223)\end{array}$ & $\begin{array}{l}-0.552 * \\
(0.297)\end{array}$ \\
\hline $\operatorname{expC} *$ wgi & $\begin{array}{l}0.019 \\
(0.057)\end{array}$ & $\begin{array}{l}0.005 \\
(0.071)\end{array}$ & $\begin{array}{l}-0.070 \\
(0.096)\end{array}$ & $\begin{array}{l}0.032 \\
(0.069)\end{array}$ & $\begin{array}{l}-0.004 \\
(0.063)\end{array}$ & $\begin{array}{l}0.016 \\
(0.072)\end{array}$ \\
\hline bit*wgi & $\begin{array}{l}-0.428 * * \\
(0.192)\end{array}$ & $\begin{array}{l}-0.456^{* *} \\
(0.214)\end{array}$ & $\begin{array}{l}-0.618^{* *} \\
(0.250)\end{array}$ & $\begin{array}{l}-0.395 * \\
(0.227)\end{array}$ & $\begin{array}{l}-0.476^{* *} \\
(0.196)\end{array}$ & $\begin{array}{l}-0.459 * \\
(0.277)\end{array}$ \\
\hline \multicolumn{7}{|c|}{ Manufacture Industry } \\
\hline wgi & $\begin{array}{l}-0.823 * * * \\
(0.133)\end{array}$ & $\begin{array}{l}-0.930 * * * \\
(0.155)\end{array}$ & $\begin{array}{l}-0.702 * * * \\
(0.172)\end{array}$ & $\begin{array}{l}-0.826^{* * * *} \\
(0.146)\end{array}$ & $\begin{array}{l}-0.718^{* * *} \\
(0.128)\end{array}$ & $\begin{array}{l}-0.399 * * \\
(0.187)\end{array}$ \\
\hline $\operatorname{expC} *$ wgi & $\begin{array}{l}0.108 * \\
(0.062)\end{array}$ & $\begin{array}{l}0.089 \\
(0.073)\end{array}$ & $\begin{array}{l}0.138 * \\
(0.078)\end{array}$ & $\begin{array}{l}0.041 \\
(0.069)\end{array}$ & $\begin{array}{l}0.097 \\
(0.065)\end{array}$ & $\begin{array}{l}0.005 \\
(0.083)\end{array}$ \\
\hline bit*wgi & $\begin{array}{l}0.055 \\
(0.119)\end{array}$ & $\begin{array}{l}-0.009 \\
(0.129)\end{array}$ & $\begin{array}{l}0.186 \\
(0.163)\end{array}$ & $\begin{array}{l}0.005 \\
(0.133)\end{array}$ & $\begin{array}{l}-0.133 \\
(0.115)\end{array}$ & $\begin{array}{l}-0.226 \\
(0.171)\end{array}$ \\
\hline \multicolumn{7}{|c|}{ Financial Services Industry } \\
\hline wgi & $\begin{array}{l}-0.630 * * * \\
(0.224)\end{array}$ & $\begin{array}{l}-0.816^{* * *} \\
(0.277)\end{array}$ & $\begin{array}{l}-1.040 * * * \\
(0.341)\end{array}$ & $\begin{array}{l}-0.644 * * \\
(0.257)\end{array}$ & $\begin{array}{l}-0.725 * * * \\
(0.241)\end{array}$ & $\begin{array}{l}-0.335 \\
(0.347)\end{array}$ \\
\hline $\operatorname{expC} *$ wgi & $\begin{array}{l}0.071 \\
(0.115)\end{array}$ & $\begin{array}{l}-0.046 \\
(0.156)\end{array}$ & $\begin{array}{l}0.013 \\
(0.150)\end{array}$ & $\begin{array}{l}0.021 \\
(0.129)\end{array}$ & $\begin{array}{l}0.046 \\
(0.140)\end{array}$ & $\begin{array}{l}0.137 \\
(0.126)\end{array}$ \\
\hline bit*wgi & $\begin{array}{l}0.442 * \\
(0.226)\end{array}$ & $\begin{array}{l}0.524 * * \\
(0.260)\end{array}$ & $\begin{array}{l}0.950 * * * \\
(0.343)\end{array}$ & $\begin{array}{l}0.425 \\
(0.263)\end{array}$ & $\begin{array}{l}0.471 * * \\
(0.231)\end{array}$ & $\begin{array}{l}0.283 \\
(0.320) \\
\end{array}$ \\
\hline
\end{tabular}

Note. Equation (1) is regressed by industry grouped. $* * * \mathrm{p}<0.01, * * \mathrm{p}<0.05, * \mathrm{p}<0.1$.

\subsection{Explanations behind the Differentiated Effect of Experience or Bilateral Investment Treaty}

In three industries in which Chinese firms are attracted to high risk countries, we find different roles of investment experiences and bilateral investment treaty and this difference is a result of industry characteristics.

In resource industry, experience has no significant effect on investment scale. The intuition behind this is obvious. Chinese resources companies are all state-owned and one of their most important responsibility is guarantee the stable resource supply in domestic market. In certain circumstances, even though these companies know some country's risk is too high, they have to invest or trade with it. In this case, of course investment experience has no effective effect. However, the BIT can be useful. If a resource-abundant but risky country has a BIT with China, Chinese companies may invest more since there're less competition from advanced economies and the foreign government's default risk is lower.

In manufacture industry where many investing firms are not SOEs, we can see investment experience begin to be effective while BITs are basically not useful since private firms are small in general and thus will not be paid too much attention by either foreign nor domestic government. 
In financial services industry, financial firms might be forced to like risky countries since in most advanced economies, there are stricter regulation rules for financial firms to enter. Being the industry most sensitive to risk, financial service industry may have a set of own risk measurement system and do not rely too much on previous experience but it will use BITs as an effective sign to update their assessment on risk.

\section{References}

Amighini, A. A., Rabellotti, R., \& Sanfilippo, M. (2013). Do Chinese state-owned and private enterprises differ in their internationalization strategies? China Economic Review, 27, 312-325. https://doi.org/10.1016/j.chieco.2013.02.003

Arnold, J., \& Javorcik, B. (2009). Gifted kids or pushy parents? Foreign direct investment and plant productivity in Indonesia. Journal of International Economics, 79(1), 42-53.

Asiedu, E. (2006). Foreign Direct Investment in Africa: The Role of Natural Resources, Market Size, Government Policy, Institutions and Political Instability. The World Economy, 29(1), 63-77. https://doi.org/10.1111/j.1467-9701.2006.00758.x

Buckley, P. J., Clegg, L. J., Cross, A. R., Liu, X., Voss, H., \& Zheng, P. (2007). The Determinants of Chinese Outward Foreign Direct Investment. Journal of International Business Studies, 38(4), 499-518.

Buckley, P. J., Clegg, L. J., Cross, A. R., Liu, X., Voss, H., \& Zheng, P. (2009). Erratum: The Determinants of Chinese Outward Foreign Direct Investment. Journal of International Business Studies, 40(2), 353-354. Retrieved from http://www.jstor.org/stable/25483379

Chen, Z. Y., Tian, Y., \& Han, D. L. (2018). Ownership Types and the Location Choice of Chinese Enterprises' Outward Direct Investment: A Transaction Costs Perspective. World Economics and Politics (06), $108-130+159$

Gani, A. (2007). Governance and foreign direct investment links: evidence from panel data estimations. Applied Economics Letters, 14(10), 753-756. https://doi.org/10.1080/13504850600592598

Ge, S. Q., \& Yan, D. Y. (2012). China's Direct Investment in United States-Facts, Logics and Trends. Journal of International Economic Cooperation, 22-26.

Globerman, S., \& Shapiro, D. (2002). Global Foreign Direct Investment Flows: The Role of Governance Infrastructure. World Development, 30(11), 1899-1919. https://doi.org/10.1016/S0305-750X(02)00110-9

Guo, J. (2015). History and Changes of Shougang Peruvian Iron Ore Project. The Journal of International Studies, 36(1), 51-73.

Huang, M. B., Tang, Z. M., \& Li, X. Y. (2019). Has the Investment Experience Affected the Model Selection of OFDI for Chinese Heterogeneous Firms. Journal of International Trade, (7), 128-141.

Jiang, G. H., \& Jiang, D. C. (2012a). China's Investment in Developing Countries - Does the Host Country's Institution Matter? Management World, (11), 45-56.

Jiang, G. H., \& Jiang, D. C. (2012b). Location Determinants of China's Outwards Investment - A Panel-Data Analysis based on Gravity Mode. World Economy, (9), 21-40.

Kolstad, I., \& Wiig, A. (2012). What determines Chinese outward FDI? Journal of World Business, 47(1), 26-34. doi:10.1016/j.jwb.2010.10.017

Li, T., \& Pi, J. C. (2019). A Study on the Motivation of China's Reverse and Forward OFDI: A Literature Review. Economist, (03), 43-51.

Liu, M., Liu, J. S., \& Li, Y. P. (2016). Home Country Investment Motivation, Host Ccountry Institution and Foreign Direct Investment Determinant. Inquiry into Economic Issues, (8), 100-112.

Lu, M. H. (1999). Institutional Factors and Foreign Direct Investment Location Choices-An Empirical Study. Economic Research Journal, (7), 57-66.

Mayer, T., \& Zignago, S. (2011). Notes on CEPII's Distances Measures: The GeoDist Database. CEPII Working Paper (2011-25), 1-12+43-48.

Ramasamy, B., Yeung, M., \& Laforet, S. (2012). China's outward foreign direct investment: Location choice and firm ownership. Journal of World Business, 47(1), 17-25. https://doi.org/10.1016/j.jwb.2010.10.016

United Nations Conference on Trade and Development. (2019). World Investment Report 2019. New York: United Nations. 
Wang, S. L., \& Xiang, J. J. (2015). Institutional Quality, Investment Motivation and China's Outward Direct Investment Location Choices. Journal of Finance and Economics, (5), 134-144.

Wang, Y. Q., Du, J. L., \& Wang, K. (2014). The Determinants of Location Choices of China's ODI: Institutions, Taxations and Resources. Economic Research Journal, (12), 126-142.

Wang, Y. Z., \& Xu, P. Y. (2018). China's Direct Investment in Latin America: Facts and Characteristics. Journal of Latin American Studies, 40(3), 51-71.

Wang, Y. Z., \& Zhao, Q. F. (2016). Risk Preference, Investment Motives and China's Outward Direct Investment: Panel Data Analysis. Chinese Review of Financial Studies, (4), 1-17+124.

Wei, S. J. (2000). Local Corruption and Global Capital Flows. Brookings Papers on Economic Activity, (2), 303-354. Retrieved from http://www.jstor.org/stable/2667361

Xu, P. Y., \& Wang, Y. Z. (2018). See Through the Fog: Investment in Latin American. China Forex, (22), 32-33.

Zong, F. Y., Lu, J. Y., \& Wu, C. Q. (2012). Bilateral Investment Treaties, Institutional Environment and Outward FDI Location Choices of Firms-An Empirical Study of Chinese Listed Firms. Economic Research Journal, (5), 71-82.

\section{Notes}

Note 1. For more information, Please find it at https://www.reuters.com/article/codelco-minmetals-gaby-idUSN2338712620080923

Note 2. i does not represent firm id since the dataset is not panel.

Note 3 . For some investment, investing body is not one firm, about $4.7 \%$ of invest in our dataset were executed by more than one firm.

Note 4. Other industry includes Management of Companies and Enterprises, Educational Services and Other Services (except Public Administration) according to NAICS 2012.

Note 5. Results for other industries will be provided upon request.

\section{Copyrights}

Copyright for this article is retained by the author(s), with first publication rights granted to the journal.

This is an open-access article distributed under the terms and conditions of the Creative Commons Attribution license (http://creativecommons.org/licenses/by/4.0/). 